IMÁGENES Y PALABRAS 



\title{
¿COMO ESTAREMOS DENTRO DE UNA DÉCADA? ANÁLISIS DE LA PROYECCIÓN POBLACIONAL DE LA PIRÁMIDE ESPAÑOLA EN 2022
}

\author{
HOW CAN WE BE IN A DECADE? \\ Analysis of the pyramid projection Spanish population in 2022
}

Francisco José Morales Yago

Universidad Nacional de Educación a Distancia

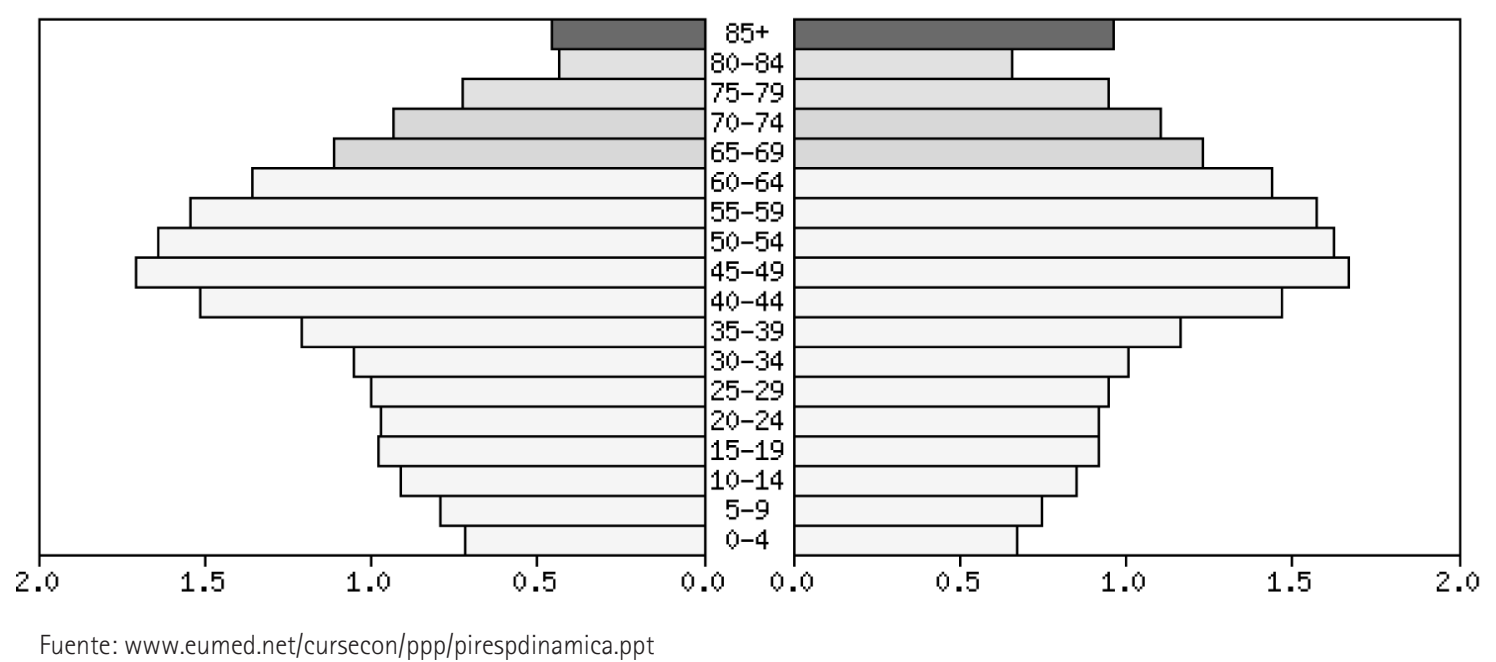

La vorágine vivida en nuestro país en estos últimos años ante la grave crisis económica del Estado, las entidades financieras y la mayor parte de la población en general ha dejado en un lugar olvidado otras crisis que tienen un gran peso específico en el bienestar de los ciudadanos. Una de esta es la que se aproxima poco a poco y será muy difícil predecir sus consecuencias aunque podremos intuir alguna de ellas así como una serie de problemas asociados que tendrán que resolverse de forma eficaz. Se trata por supuesto de la situación demográfica de nuestro país y más concretamente del acelerado envejecimiento de la población que estamos experimentando, ello ha sido debido al aumento de la esperanza de vida y esencialmente al descenso de la natalidad. Desde finales de los años setenta la edad media de la población aumenta y su tamaño está llamado a disminuir en algún momento futuro.
Los datos en la proyección demográfica que hemos realizado para la próxima década en caso de mantenerse las tendencias y los comportamientos demográficos actualmente arrojarian una situación porcentual significativa, así el descenso paulatino de la natalidad tendría como primera consecuencia una reducción de los niños menores de cinco años en 421.020 efectivos (un 16,5\%) entre 2012 y 2022. De hecho en es este último año el porcentaje de los menores de 16 años quedaría reducido a un 25,14\% del total de la población.

Por el contrario, en el resto de grupos de edad la población crecería, así el número de personas mayores de 64 años se situaría en el año 2022 en un 32,75\%, mientras que el colectivo de las personas en edad activa, entre 16 hasta 64 años alcanzaria el $42,11 \%$ del total de la población. Si hallamos la tasa de dependencia que sería la suma de los me- 
nores de 16 años y los mayores de 64 años llegariamos a la cifra record de un 57,89\% del total de la población. En términos absolutos pasaríamos de una población censada el 1 de Enero de 2012 de 47.212 .900 habitantes a 46.718 .181 personas en 2022.

En el año 2012 el crecimiento vegetativo que es la diferencia entre el número de nacimientos por cada mil habitantes $(10,44)$ y de defunciones $(8,6)$ indica un dato de un tasa de 1,84. Continuando con esta trayectoria en el año 2019 entraremos en crecimiento vegetativo negativo $(8,87$ nacimientos) y $(9,04)$ lo que reflejará un $-0,17$. En todo caso el relevo generacional que supondría el nacimiento de 2,1 hijos por mujer desde hace bastantes años no está garantizado, en 2012 dicha tasa se sitúa en 1,47.

Según nos informa el Instituto Nacional de Estadistica la prolongación de las tendencias demográficas actualmente observadas a los próximos 10 años conllevaría a que ocho comunidades presentaran decrecimientos poblacionales en el conjunto del periodo 2012-2022, estas serían: Cataluña,
País Vasco, Castilla y León, Comunidad Valenciana, Galicia, Principado de Asturias, La Rioja y Extremadura.

En siete comunidades el número acumulado de defunciones superaría al de nacimientos en la próxima década. Así, el saldo vegetativo entre 2012 y 2022 resultaría negativo en Galicia, Castilla y León, Principado de Asturias, País Vasco, Extremadura, Aragón y Cantabria.

La frialdad de los datos nos invita a reflexionar sobre el futuro más inmediato de la población española, es cierto que hemos alcanzando una de las tasas de natalidad más bajas del mundo y que cada vez vivimos más, ante ello será conveniente pensar que medidas serán necesarias para evitar el "invierno demográfico" al que nos acercamos, ¿Cómo podremos mantener las pensiones y atención sanitaria de las personas mayores?; ¿Tendremos que convertir nuestros centros educativos en geriátricos? ¿Será la inmigración la solución ante los problemas demográficos?

Francisco José Morales Yago Universidad Nacional de Educación a Distancia 